\title{
2. \\ Habent sua fata: \\ Writing life histories of Roman Sarcophagi
}

JANET Huskinson

'Quel che il poeta dice dei libelli, vale anche e sopra tutto per i sarcofagi: questi pure habent sua fata': thus the great scholar of early Christian sarcophagi Josef Wilpert started his 1923-24 article about some particular examples which he had recently recorded for his corpus of I sarcofagi cristiani. ${ }^{1}$ Many of these had been cut up or wrongly re-assembled for display in new contexts that were quite different to their original funerary purpose, leading him to lament the postclassical fortunes of Roman sarcophagi as so often 'rather sad'.

This rather negative assessment of their reception is perhaps not surprising since Wilpert himself was primarily interested in the iconography of their figured decoration and its relationship to contemporary religious ideas, and subsequent changes of use and setting often caused damage - physical and conceptual - that made it near impossible to retrieve these original values. But, as the papers in this volume show so well, the study of Roman sarcophagi in their ancient contexts now draws on many different approaches - commercial, cultural, aesthetic, as well as iconographical - and these may also be applied to evaluating their re-use in post-classical societies. This too involved a broad range of values, for evidence shows that at one time or another ancient sarcophagi were regarded as classical art-works or antiquities, chosen as suitable tombs, fountains or decorative containers, or taken as symbols of the Roman tradition or even as poetic metaphors for life and death. ${ }^{3}$ Yet on the other hand they were sometimes re-deployed with little apparent interest in their ancient past. This wide range of possibilities opens the way to more positive evaluations of how later societies re-used Roman sarcophagi than Wilpert could give. But at the

1 Wilpert 1929-1936; Wilpert 1923-1924: 'What the poet said about books, is true too - and most of all - of sarcophagi: they have their own fates.' The poet was Terentianus Maurus. Wilpert's statement echoes that made by C.Robert 1900, 98 on a sarcophagus at Cliveden.

2 Wilpert 1923-24, 168-69.

3 The theme of sarcophagi having a new existence as life-giving fountains or fonts was treated by several baroque poets interested in exploring 'metamorfosi e la dilettica fra Vita e Morte': Federici 2002, 277-279. This is a reminder of how re-used material objects, such as sarcophagi, also have values as literary symbols. 
same time it is also a potential obstacle to finding a single interpretative approach that could be used to accommodate all the different circumstances of re-use.

For to avoid ending up with a virtual list of individual types of re-use, what is needed is an evaluative framework that can transcend all this variability. But this is particularly hard to identify because of the essentially functional nature of sarcophagi, which as durable, useful, and often beautiful containers, could be redeployed in many different ways and settings. The values involved in this re-use could shift from one context to another, and vary between locations and over time, creating a complex and many-layered set of meanings even for a single sarcophagus. This means that interpretative approaches that have been evolved for assessing the re-use of one particular type of ancient material may only work for some sarcophagi, some of the time, and are not generally applicable. For instance, not all sarcophagi can be usefully discussed in terms of architectural spolia (a category of ancient material which has rather dominated recent studies of re-use); and, although some sarcophagi were copied by later artists as influential stylistic models, as a whole they did not attract the rich array of visual and literary responses needed to support the kind of reception-based approach useful for ancient art works which became established cultural icons. ${ }^{4}$

Multi-disciplinary approaches, on the other hand, have proved much more effective in coping with the variations, especially where they have been employed to survey the full range of values attached to the re-use of Roman sarcophagi within a specific context. These contexts have usually involved a particular time or place, as, for instance, in the studies of Ragusa 1951 and Elsner 2009, and in the papers included in Andreae and Settis 1984. But in the quest for a single transcendent approach, some of the most helpful work has dealt with conceptual contexts, as two recent articles by Settis exemplify.

The first (Settis 2004) was written as the introduction to a catalogue of photographs which document the re-use of ancient material - including sarcophagi - in the city of Rome; and in it Settis systematically sets out a series of questions and criteria for addressing different aspects of this kind of re-use. These involve five 'key words' - Assenza (representing an emptiness waiting to be filled), Presenza (of models surviving from antiquity, to be re-used in new contexts and functions), Selezione (process of choosing models for new uses), Citazione (using spolia to create quotations from the past), and Topos (repeatable formulae which help to construct the visual argument). ${ }^{5}$ Together these form a sequential process for analysis and evaluation, which can accommodate even the

4 For a survey of some recent work on Spolia see Stenbro, 2005. For Vasari on Nicola Pisano, see Settis 2004, 14; and also Bober-Rubinstein 1986. For reception of an ancient work of art: Prettejohn 2006 (on the Venus de Milo).

5 Settis $2004,15-19$. 
multifarious situations presented by sarcophagi. (These key words recall terms proposed in other studies, which are also useful for evaluating re-used sarcophagi: Continuità, distanza, conoscenza, which were formulated by Settis himself in 1986, and 'spolia in se' and 'spolia in re', by Brilliant 1982, to which Cutler 1999 added 'in spe'). ${ }^{6}$ The second discussion (Settis 2008) has a more specific historical focus, as Settis explores the great popularity of Roman sarcophagi amongst various elite groups in the Middle Ages, who used them as a way of confirming contemporary power through the authority of the past. This chapter (which appears in a volume on collecting sculpture in early modern Europe) is a brief but pointed discussion, which presents the sarcophagi rather as commodities in which different values are invested according to the specific context of their re-use. ${ }^{7}$

Here, then, is one single approach - namely, the treatment of sarcophagi as commodities, or potentially valuable objects - that can accommodate variations in value that arise from different circumstances. It offers a pathway through all the shifts and fluctuations that characterise their use and re-use right from the time of manufacture, which the rest of this paper will aim to follow.

An obvious way to test out where it can lead is to take individual sarcophagi and trace the various contexts in which they have been used and re-used over time - in other words, to write something akin to their 'life histories'. This kind of biographical approach has been developed recently as an interpretative tool in social history (with the 'life-course' of individuals) and in archaeology and material studies for evaluating the changing significance of objects. ${ }^{8}$ It ' $\ldots$ seeks to understand the way objects become invested with meaning through the social interactions they are caught up in. These meanings change and are re-negotiated through the life of the object'. ' In other words, this is a method which is actually geared to deal with the kind of changes and fluctuations which the sarcophagi present across their entire existence. Although Kopytoff, in a seminal essay on

6 Settis 2004, 15-18; Settis 1986; Brilliant 1982, 2-17: 'in se' represents the physical reuse of an object itself; 'in re' the use of an ancient object as a model; and Cutler 1999, 1064, 'spolia in spe' 'are things used in the anticipation that they will be seen to complete an object, or at least add to a new creation valences that are not communicated in their absence'.

7 E.g. Settis 2008, 14; 19. Verkerk 2007 also considers sarcophagi as objects of re-use (rather than for art-historical classification), but from the point of view of the secondary patron rather than 'object biography' per se.

8 For discussions of this approach e.g. Gosden and Marshall 1999, Hoskins 2006. Appadurai 1986 was a major influence from material studies. Biography and the lifecycle are now frequently used as approaches to ancient social history and archaeology: e. g. Robb 2002; Harlow and Laurence 2002. Greenhalgh 1989 describes his study of the survival of Roman antiquities into the Middle Ages as partly 'an interpretative "biography" of various classes of antiquities'.

9 Gosden and Marshall 1999, 170. 
writing artefact biographies, focused on objects as commodities in a strict economic sense, sarcophagi may benefit from taking a wider, more inclusive approach to writing their life stories. After all, their contexts of use may involve not only the kinds of circulation and transaction that define commodities, but also the need to keep and preserve in respect of some intrinsic value (attached to them as antiquities or reliquaries, for instance); and this variation means that they may get invested with a wide array of cultural, religious, political and social meanings. ${ }^{10}$

In addition to the meanings they derive from such social interactions, there is a particular metaphorical connection between sarcophagi and biography which makes this kind of approach especially relevant. For more than almost any other object, they are intimately related to the life of the human body and its changes over time: as containers for the dead they 'consumed' the physical body inside, while providing it with an enduring 'monumental body' which represented ideal social qualities or life-events. ${ }^{11}$ As biography is an obvious way of presenting the changing values of a human life, so it should be for the different phases of a sarcophagus' existence. ${ }^{12}$

So this paper will test out the merits of a biographical approach by focusing on three Roman sarcophagi, which have been chosen because their long life histories contain an interesting range of 'events' and are well-documented in published sources. ${ }^{13}$ It will first attempt to draft their outline biographies, from their creation to the present-day, and then move on to discuss some of the changing values and meanings that these represent.

\section{'The Pianabella Sarcophagus', Ostia Museum inv. No. 43504, on perma- nent loan from Antikenmuseum, Berlin (Figure $2.1 \mathrm{a}, \mathrm{b}$ and c)}

Imported Proconnesian marble was used for this sarcophagus, and its decoration seems to have been carved around 160 by sculptors in or near Rome. ${ }^{14}$ On the front are three scenes inspired by the Iliad - on the left, the arming of Achilles in the presence of his mother Thetis, followed by Achilles'

10 Kopytoff 1988; Rowlands 2005.

11 For funerary monuments and the physical body: e. g. Llewellyn 1991, 46-49.

12 But while the lives of those once buried within them are finished, sarcophagi continue to exist (although others were destroyed, by being converted into lime - ultimately another form of re-use).

13 Because the prime point of this paper is to illustrate the opportunities of this approach, these narratives are simply written from published sources without recourse to archives or private correspondence etc., that could perhaps fill out (or even alter) some of the details given here.

14 Morandi 1993, 152. Paroli 1999, 219 gives the dimensions as H. 54.5, L.195, D. 62. Lid: H: 23.5, L. $200 \mathrm{cms}$, greatest depth 15 . For main bibliographic references to the piece see Paroli 1999, 221 -222, no. B8; ASR XII,1 44-48, 204-05, no. 27 pl 28-31; Dresken-Weiland 2003, 331, A91; Zanker and Ewald 2004, 283-285. 


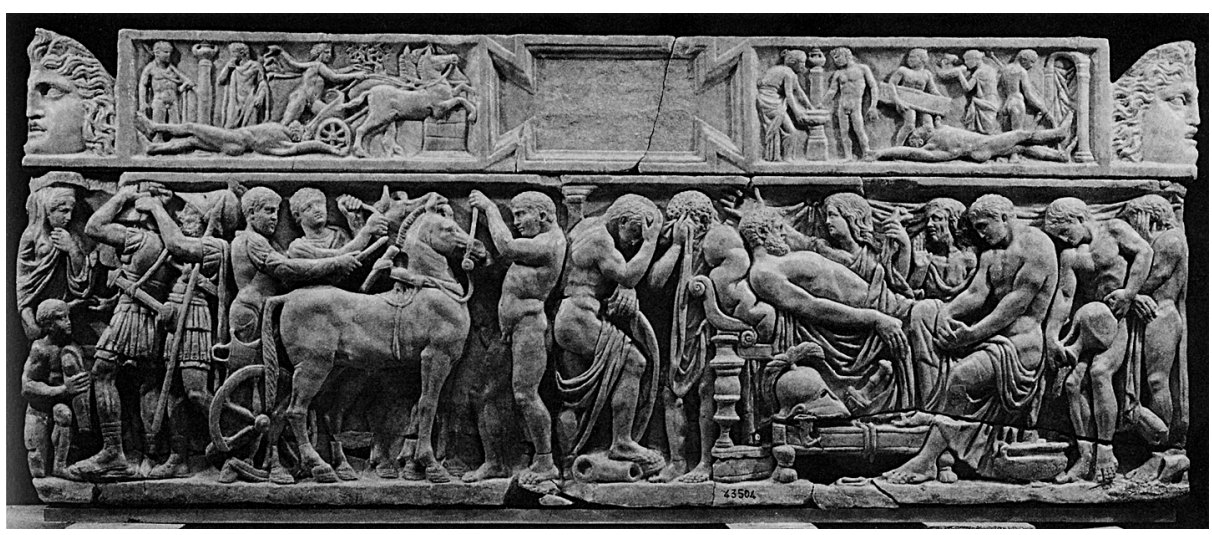

Figure 2.1: 'The Pianabella Sarcophagus' Ostia Museum inv. No. 43504, on permanent loan from Antikenmuseum, Berlin. Photograph: courtesy of the Archivio Fotografico della Soprintendenza per i Beni Archeologici di Roma, Sede Ostia Antica.

chariot guided by Automedon, and on the right an extended scene of Achilles mourning the dead Patroclus. Griffins decorate the side panels. The lid has further scenes from the Iliad flanking the inscription panel: on the left Achilles is shown in his chariot dragging Hector's corpse around Patroclus' tomb, and on the right the washing of Hector's body prior to its restoration to Priam.

Individually these scenes resemble episodes in the life of Achilles as represented on Attic sarcophagi, but they include iconographical features in the iconography (such as the death-bed scene) of Roman derivation. From this it has been deduced that the sarcophagus was decorated in or around Rome, possibly taking an Attic sarcophagus imported through Ostia as its model. ${ }^{15}$

These Roman elements in the imagery of Achilles are unique and suggest that the sarcophagus may have been specially commissioned. The choice of Greek literature as the basis of its decoration and the conspicuously high quality of the figured scenes, exquisitely carved on expensive marble, suggest that whoever commissioned it was wealthy and cultivated. A possible candidate has been proposed - a leading Ostian family, the Egrili, who appear - from other archaeological traces - to have had a funerary complex in the necropolis of Pianabella, outside Ostia. ${ }^{16}$ Whatever the case, no evidence survives to show where the sarcophagus was deposited, or how it might have been displayed within the tomb.

The next attested stage in the life of the sarcophagus is its re-use, sometime in the third century, in another mausoleum in the Pianabella cemetery. Its

15 E.g. Koch and Sichtermann 1982, 130; Giuliani 1989; ASR IX,1, 72; ASR XII,1, 4448.

16 Morandi 1993,154. 
original inscription was erased, making it ready to accommodate another generation of dead whose family must have been pleased to have acquired (but how?) such a high quality marble sarcophagus to use for burial.

This mausoleum was at the northern end of the row of tomb-buildings in the cemetery. ${ }^{17}$ It was originally erected sometime in the first half of the second century but underwent various re-arrangements during the second and third centuries. ${ }^{18}$ In one of these the sarcophagus was installed below floor-level, in a forma which was specially made to accommodate it; a wall was built along its front and mortar poured in to fill the spaces left around it. ${ }^{19}$ The sarcophagus was now out of sight, buried below ground, presumably to protect it (as both a valuable piece of marble and a container of the dead) against any further re-use.

Over seventeen centuries passed before the next known episode in the life of this sarcophagus, which turned it into an object of value in the illicit trade in antiquities, and then in international negotiations about the return of cultural property. Sometime, probably, in 1976 it was discovered in situ by clandestine excavators, who looted the front, parts of the side panels and the lid, leaving the rest behind. ${ }^{20}$ Obviously they managed to take most of the figured reliefs, which were high-value commodities in the art market, but were presumably frustrated in attempts to get the whole sarcophagus out of the ground. By 1982 these fragments had entered the Berlin Antikenmuseum at Charlottenburg. They had been acquired on the assurance of a 'previous owner' that they had come from a Swiss private collection where they had been for at least a generation, and where they had once been set into a wall to serve as a flower container. ${ }^{21}$ But by then the rest of the sarcophagus, left in situ by the clandestini, was found at Pianabella, and the freshness of the breaks gave strong suggestion that the story of a previous Swiss owner was untrue. From 1988 to 1991 Italian archaeologists carried out a systematic excavation of the mausoleum and discovered how the sarcophagus had been installed below ground, as described above. What is more they found impressions left in the mortar by the figures carved on the front and sides of the sarcophagus. These were the final proof that the reliefs in Berlin had come from this tomb.

But even so - to follow Heilmeyer - criminal investigations proved fruitless. There also seemed to be no legal grounds for requiring that the fragments should be restored to Ostia. On the other hand, scholarship was seen to provide

17 Paroli 1999, 20. The mausoleum is designated as L1 in area 7000 of the necropolis excavations.

18 Morandi 1993, 149; 151 fig.8.

19 Morandi 1993, 149; 152 fig. 9; Paroli 1999, 220, Fig 9.

20 Morandi 1993, 150 figs 2 and 3 for sections of the sarcophagus in Berlin and Ostia, and fig 4 for the sarcophagus re-composed.

21 Giuliani 1989, 27, n.8 and Heilmeyer 1992, 265-267. 


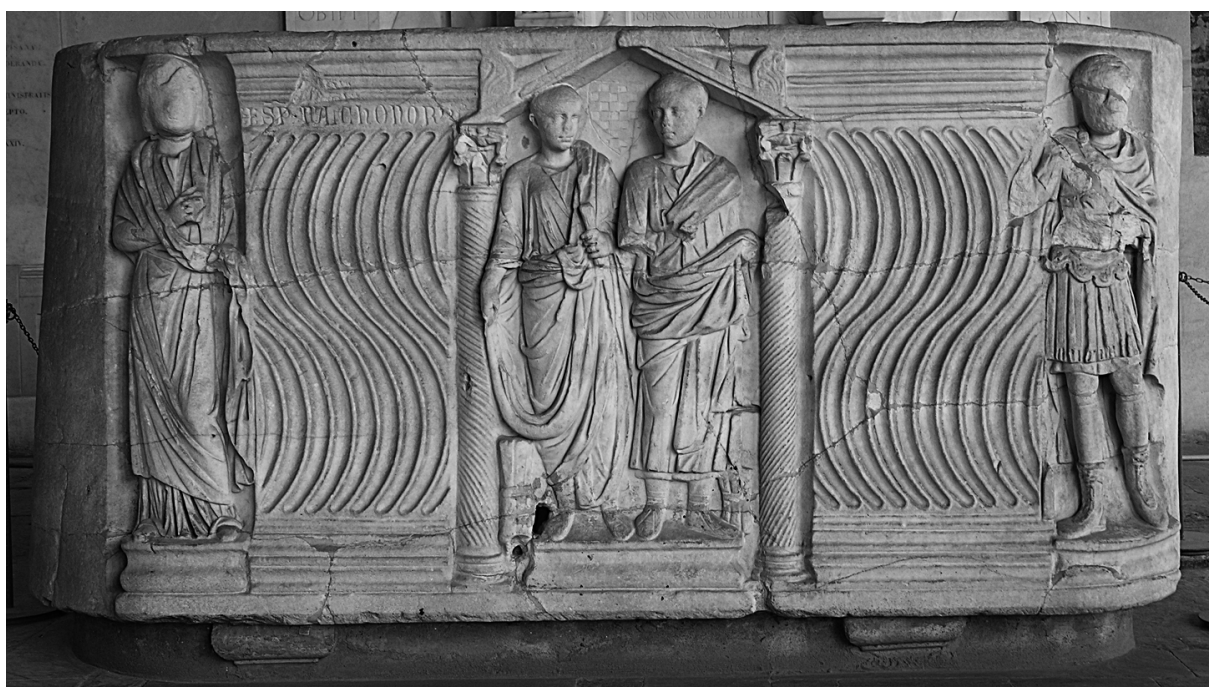

Figure 2.2: Pisa, Camposanto B 1 est, ' The Brothers' sarcophagus'. Pisa, Camposanto. Photograph: J. Elsner.

cogent arguments for reuniting the different parts of the sarcophagus, and as an agreed solution the sections in Berlin were sent on permanent loan to Ostia, where they are now displayed together with the rest, creating a whole, but badly damaged, sarcophagus with lid.

\section{'The Brothers' sarcophagus', Pisa, Camposanto, B 1 est. inv. no. (1963) 188 (Figure 2.2)}

This sarcophagus has the tub-like form of a lenos, with curved sides. ${ }^{22}$ The front is decorated by three figured panels separated by two sections of curved fluting which are set between heavy borders. In the centre two young men are shown standing within an aedicula, which is supported by two spirally fluted columns. They wear togas (of different styles) and shoes of a type that suggests senatorial status; the youth on the left holds a scroll, and there are bundles of scrolls at their feet. They stand on a low plinth, as do the single figures in the corner panels - a draped woman on the left and a military man on the right. Both of these figures half turn towards the centre, and were intended to have portrait features, which were never carved. The sides and back of sarcophagus are smooth, but the back is decorated with two lion heads, with rings in their

22 The main references, with detailed descriptions and bibliographies are: Arias, Cristiani and Gabba 1977, 113-14, B1 est; Aquarius (entry compiled by F. Donati) Doc. no SNSSARC00150; ASR VI,1,110 Kat 50; Wrede 2001, 124-25 no. 15; and ASR I,3, 36, 208, Kat no. 54. Reinsberg there gives the measurements as: H. 1.30, L. 2.80, D. $1.54 \mathrm{~ms}$. The front figures, in particular, are quite damaged in places. 
mouths, carved in high relief (and placed, unusually, at the very top of the sarcophagus).

These lion heads, and their unusual position on what is now the back of the sarcophagus suggest several things about the earliest stages in its life. As a large number of other examples testify, they were originally intended to decorate the front, within a decoration of strigillations. ${ }^{23}$ Evidence shows that sarcophagi of this type were exported from quarries in Asia Minor partly prefabricated, for their decoration to be finished in Rome. ${ }^{24}$ Some found in the San Pietro shipwreck off Taranto were said to have been made of a marble similar to this example in Pisa, which probably came from quarries in Thasos. ${ }^{25}$ In this case, it looks as if decisions were taken to alter the planned decoration after the halffinished sarcophagus had arrived in Rome: the lion heads were completed (though not the strigils that usually surrounded them), and a set of figured scenes was carved on the other long side, thus turning it into the front. ${ }^{26}$ But quite how many stages of work this involved and quite when these may have been completed is uncertain: opinions have diverged about the relative dating of the portraits (generally assigned to 220s) and lion heads, and about whether all the decoration was carved at the same time. ${ }^{27}$

The figured scenes - which show a couple in the centre and a man and woman individually in the corners - have clear resonances with those on what Reinsberg has termed the 'Feldherrn/Hochzeit-Sarkophage' in which men and women are shown both as individuals and also together, usually in a central scene of dextrarum iunctio representing their marriage. ${ }^{28}$ Even so there are significant differences: here neither the man nor the woman is shown engaged in any activity, such as sacrifice, while the central scene contains the portrait figures of two young men. This is a unique deviation from the conventional iconography, and may have been specially commissioned to commemorate the premature death of the couple's sons: that is the suggestion. ${ }^{29}$ But plausible though it is, the reality is that this explanation cannot be confirmed. All in all, just who was responsible for this re-design, when and why it happened, and

23 Cf. examples depicted in ASR VI,1, pls. 8-19.

24 Ward-Perkins and Throckmorton 1965.

25 Ward-Perkins and Throckmorton 1965, 205; and Russell, this volume note 84 for further references (Cf. also Walker 1985, 62-64: this was the only sarcophagus in her sample of this type not to have been made of Proconnesian marble).

26 Andreae 1984, 110-112 and for illustrations of the back; ASR VI,1 1998, 23.

27 For views on several phases: Arias, Cristiani, and Gabba 1977,114; Walker 1985, 60; Andreae 1984, 110-11; ASR I,3, 36 n.177. But Stroszeck in ASR VI,1, 110 dates it much later, to between 280 and 300, from the type of the lion heads (but without discussion).

28 ASR I,3, 19-39. This composition is usually found on rectangular sarcophagi.

29 E.g. Reinsberg in $A S R \mathrm{I}, 3,36$. 
where the sarcophagus was finally placed in Rome have to remain unknown. Although it is a monumental piece, the carving of the figured scenes is not of the highest quality: the woman is sculpted on the front of the sarcophagus and the man on its curved corner, so that their plinths and also the adjacent panels of fluting are of different dimensions.

The next documented stage in the life of the sarcophagus occurs in fourteenth century Pisa. There it was re-used as a tomb by the Falconi family, as is revealed by the inscription added above the left-hand panel of strigillations. They were rich and influential merchants, who were regularly named amongst the Anziani, the principal Pisan magistracy. ${ }^{30}$ For many such families in Pisa at that time, to be buried in an ancient Roman sarcophagus was a symbol of their status. The attraction lay in its commercial value as an expensive import (possibly purchased direct from Rome), in its aesthetic qualities, and above all in its symbolism, as a Roman antiquity. Since the eleventh century Pisa had consciously identified itself with Rome, using Roman inscriptions and reliefs as spolia in the Duomo and other major buildings to reinforce the historical reference; by choosing Roman sarcophagi for their tombs the elite were also allying themselves to the past from which their city claimed authority. Until the Camposanto was built in the early 1300s, these sarcophagi were placed around the outer walls of the Duomo, on public view in the heart of the city. ${ }^{31}$ This was a fitting burial-place for the Pisan elite, who were identified by inscriptions on the wall above. The Falconi may have been represented there, but this seems unlikely since the re-use of this particular sarcophagus apparently dates from after the move to the Camposanto. ${ }^{32}$

Although it still remains there, this Roman sarcophagus has further stages in its life to be described since changes in the use and nature of the Camposanto itself altered the way in which its contents would be viewed and valued. ${ }^{33}$ The Camposanto had from the start a complex range of roles, sacred and civic: its cemetery had a religious function, but it was also the place where distinguished Pisans were commemorated, many buried in ancient Roman sarcophagi. Gradually, it seems, the balance came to shift, and the Camposanto changed from being a sacred space to become a secular museum of art and Pisan

30 Donati and Parra 1984, 112; 118, n. 40. The historical context of the re-use of sarcophagi from Rome and Ostia at Pisa is very well-discussed and well-documented: see e.g. Donati and Parra 1984, Donati 1984, 1993, 1996. For their influence on Pisan artists, notably Nicola Pisano, see e. g. Milone 1993, 20; Settis 2004, 14.

31 See Tolaini 2008, 54 for current debate about the date of their removal into the Camposanto. He claims that this did not happen until the early fifteenth century.

32 Cf. sources given in Donati 1984, 28 -32 (Appendice) and Donati 1996, 93-96.

33 Here too developments in Pisa are well documented: e.g. Baracchini 1993; Baracchini and Castelnuovo, 1996. 
history. ${ }^{34}$ In 1706-7 the sarcophagi were brought inside from its garden, where they had originally been placed, to shelter under the cloisters, and a printed catalogue made in $1708 .{ }^{35}$ Further changes came with the appointment in 1807 of Carlo Lasinio as Conservatore del Camposanto, who set out to consolidate the collection as a celebration of Pisa's past, and as a museum of art, along the lines of great European museums that had recently been created. ${ }^{36}$ Under Lasinio, the sarcophagi became part of the collection to be curated. He added to the collection - and its value as a secular museum - by bringing into the Camposanto sarcophagi from elsewhere in town, including some from churches. ${ }^{37} \mathrm{He}$ improved the visibility of the display, set some sarcophagi on marble bases, reallocated lids or disposed of the sarcophagus' contents. ${ }^{38}$ The Falconi sarcophagus was originally sited in the eastern part of the Camposanto, but in 1810 was moved into the western cloister, to be positioned at the end of the central row of monuments. ${ }^{39}$

Like other sarcophagi that remain in the Camposanto, it is a survivor of the antiquarium which Lasinio fostered, even though many of the other artefacts he collected as a museum of the arts have been dispersed to other locations in Pisa when new collections were set up. ${ }^{40}$ It is also a survivor of the massive war damage that afflicted the Camposanto on 27 July 1944. Today it stands with a commanding view down the south-western side of the cloister.

\section{'The Borghese sarcophagus', Louvre MA 2980 and Rome Musei Capitolini, Centrale Montemartini inv. no. 2071. (Figures 2.3 a,b, and c).}

This large sarcophagus was decorated with figured scenes on all four sides, and would originally have had a decorated lid. ${ }^{41}$ It belongs to the so-called 'City gate' series of prestigious sarcophagi that date to the late fourth century, and was probably made in Rome, and its similarity to another in Milan, raises questions

34 Milone 1993. Also Tolaini 2008 for the display element, from the early fifteenth century.

35 Donato 1984, 13-14; Milone 1993, 25-27.

36 Baracchini 1993.

37 Donati and Parra 1984, 103; Donati 1993, 97-100.

38 Donati 1993, 94; Casini 1993, 65, fig.15.

39 Settis 1984, Piantina/Itinerario nos. 1 and 2 show the location of the sarcophagus in 1708 and 1760 outside the cover of the cloister on the south-east side. Baracchini 1993, 129 ('ricostruzione grafica'); Baracchini 1996, 203, 212 for alterations to the display in this cloister soon after Lasinio's death; cf. pl.28 for recent picture of that side.

40 Baracchini, 1993 13-16 also Donati 1993, 102; 1996, 71.

41 The main references, with detailed descriptions and bibliographies are: for the back: Rep. I, no. 829; for the rest: Baratte and Metzger, 1985, no 212 ; Koch 2000, 325, no 139 ; Rep. III, no. 428; Dresken-Weiland, 2003, 378, Kat E 26. These also give the measurements as: Front and sides: H. 1.10; L. 2.52 right side: 1.4; left side 1.46. Back: H. 0.98 ; L. 2.45 ms. 


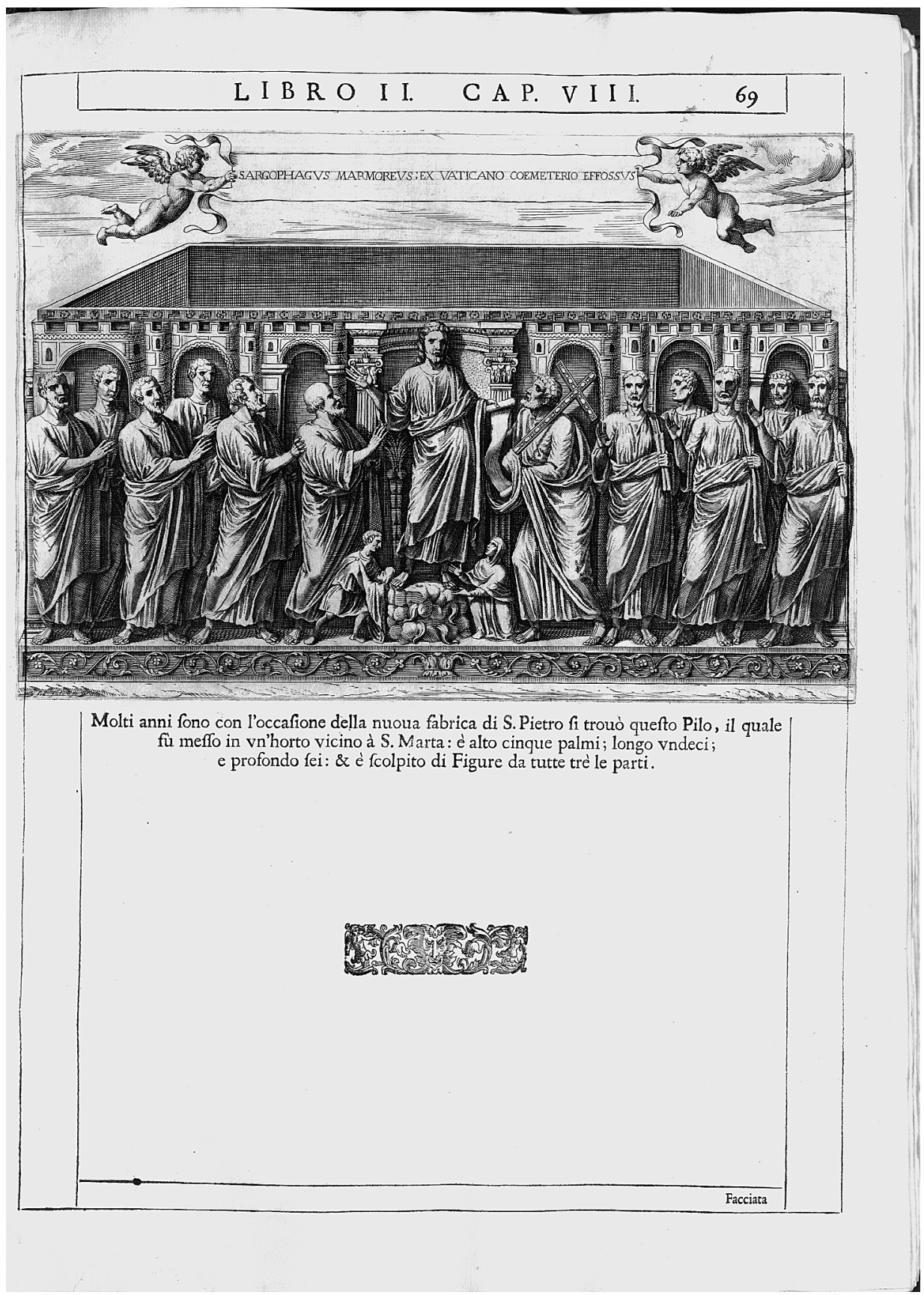

Figure 2.3a: 'The Borghese sarcophagus': front. Photograph: from Antonio Bosio, Roma Sotterranea, Rome 1632, 69 ( by kind permission of the Syndics of Cambridge University Library). 


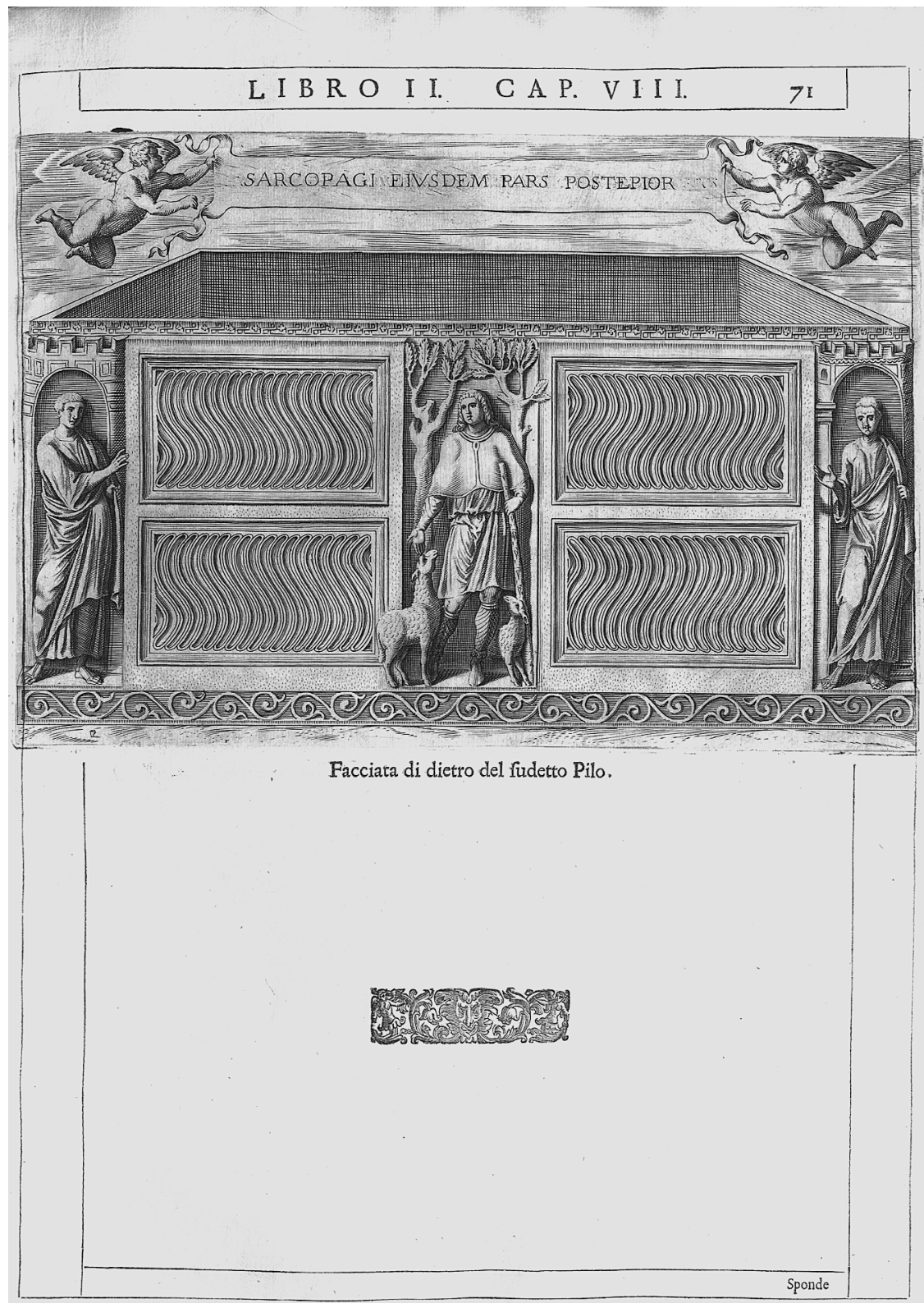

Figure 2.3 b: 'The Borghese sarcophagus': back. Photograph: from Antonio Bosio, Roma Sotterranea, Rome 1632, 71 ( by kind permission of the Syndics of Cambridge University Library). 


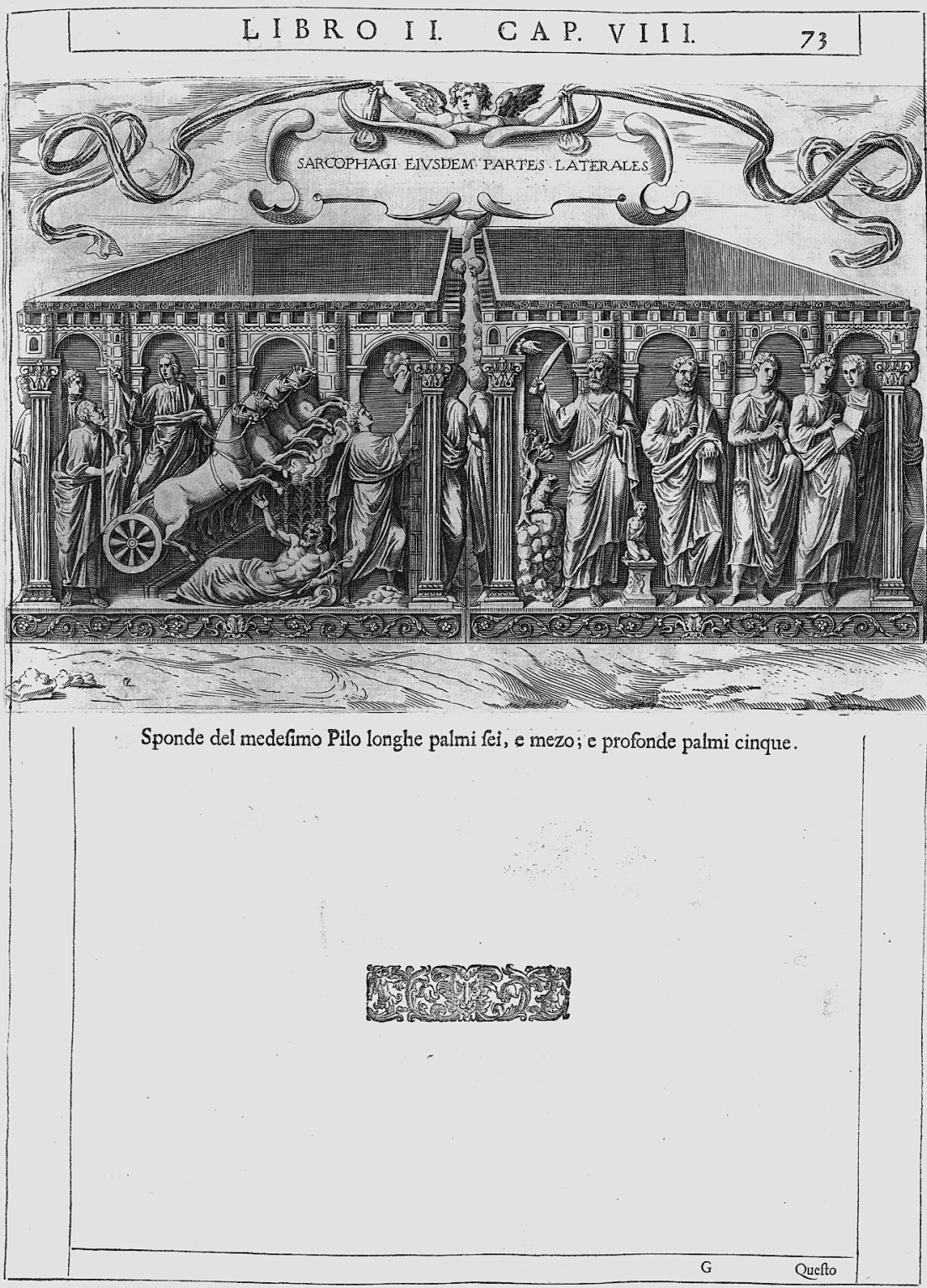

Figure 2.3c: 'The Borghese sarcophagus': sides. Photograph: from Antonio Bosio, Roma Sotterranea, Rome 1632, 73 ( by kind permission of the Syndics of Cambridge University Library). 
about their relative dating. ${ }^{42}$ The front depicts the Traditio Legis, with Christ standing on a rock from which flow the four rivers of paradise, and flanked by twelve apostles. Small figures of a man (left) and woman (right) bow at his feet, as he hands the scroll of the law to St Peter on the right, who carried a jewelled cross. The left side panel depicted the ascension of Elijah and Moses receiving the Tablets of the Law, and the right the sacrifice of Isaac and four standing men. The back had three figured scenes separated by double registered panels of strigillations: in each of the corners the figure of an apostle stands half-turned to the figure of a young shepherd at the centre. He is framed by trees, but the figures in all the other scenes are shown in front of a city wall, with crenellations and arches.

It is not known who actually commissioned the sarcophagus (although the lid, now lost, probably carried a dedicatory inscription). ${ }^{43}$ But circumstances of its discovery, as will become apparent, suggest that it was for the burial of a member or members of the Anicii family. ${ }^{44}$ Their high social standing is reflected in the quality of the sarcophagus, and possibly also in the central male figure on the right side panel who is dressed like some contemporary court official (and not in a tunic and mantle like the others). ${ }^{45}$ The sarcophagus was then placed, with at least one other (see below), in their family mausoleum. Located in a prestigious site behind the apse of St. Peter's basilica, this was built at the end of the fourth century and dedicated (according to inscriptions found there) by Anicia Faltonia Proba to her late husband, Sextus Claudius Petronius Probus who had been consul in 371 and died around $388 .{ }^{46}$ Its exact layout is unknown, nor is it certain where the sarcophagus was placed within it, although it may have been buried below the level of the floor. ${ }^{47}$

42 For this type see e.g., Sansoni 1969; Koch 2000, 304-07; Rep. III, 201. It is very similar to another in Sant'Ambrogio, Milan: Rep. II 56-58, no.150, especially 58 for summary of arguments about their relative dating and relationship.

43 Cf. lids of other 'City gate' sarcophagi: Rep. II nos. 148 (Tolentino) and 149 (Ancona).

44 Dresken-Weiland 2003, 378, Kat E 26; see also 119.

45 Cf. Rep II nos. 149 and 150 for other examples of the small kneeling figures. See Baratte and Metzger, 1985, 316 for suggestion that the man in contemporary dress is the 'destinataire du cuve'; if so it seems rather an unobtrusive place to depict him.

46 Re. mausoleum: Liverani 1999 ,147-48 no. 68; also Dresken-Weiland 2003, 118-19. For the inscription: CIL 6.1756. For Anicia Faltonia Proba and Sextus Claudius Petronius Probus see Brown 1961; Jones, Martindale and Morris 1971, $732-33$ and 736-40; Matthews 2009, 134-38.

47 It seems impossible to be completely certain that the two sarcophagi were originally buried, even if that is how they were found in the fifteenth century: e.g. Schoenebeck 1935, 108-09, amongst lime and debris. Dresken-Weiland 2003, 119 adds arguments to support the case for the original burial: i. e. that the objects found in the so-called Probus sarcophagus would not otherwise have escaped robbery, and that as fifteenth century popular belief thought the mausoleum was the tomb of St. Peter, no sarcophagus was to be seen in it. 
This is the inference to be made from the report of its discovery given by Maffeio Vegio (1405-1457), who visited the Mausoleum shortly before it was demolished in 1453 in preparation for the rebuilding of St. Peter's. ${ }^{48}$ But his description primarily focused on the other, columnar sarcophagus found there, in which garments with gold thread were discovered alongside the skeletal remains. ${ }^{49}$ This obvious sign of wealth, along with the depiction of a married couple on the back, meant that this sarcophagus was quickly associated with Probus and his wife, while the 'Borghese Sarcophagus' was assigned less distinguished inhabitants. Cesare Baronio (1538-1607), who illustrated it with two women at the feet of Christ, suggested that it was the sarcophagus of Anicia Proba Faltonia and her daughter-in-law Anicia Juliana; his inaccuracy was roundly criticised by Antonio Bosio (1575-1629), who then proposed that the man depicted was her son, Anicius Hermogianus Olybrius with his wife Juliana. $^{50}$

The sarcophagus was discovered without its lid and, to judge from copies of some late sixteenth century drawings, even by then many of its figures were badly damaged. ${ }^{51}$ When Bosio saw it, it was presumably still intact and located in the garden near the church of Santa Marta to which it had been taken sometime after its discovery. ${ }^{52}$ But soon after this it was moved to another setting in Rome, the Villa Borghese.

The Villa was developed for Cardinal Scipione Borghese (1576-1633) as a place of leisure, where he could display his collection of antiquities. ${ }^{53} \mathrm{He}$ bought sarcophagi from various sources and was also given antiquities by his uncle Pope Paul V. ${ }^{54}$ Like many others this sarcophagus was dismembered, and its front and two side panels used to decorate facades of the Casino, while the back was cut into seven pieces which were inserted into decorative facades near the so-called 'Teatro' in the Villa grounds. This new function as an object of conspicuous display sealed the fortunes of this sarcophagus to this present day.

The decoration of the Casino's facades with ancient marble sculptures was done between 1616 and 1624 to the designs of Giovanni Vasanzio, creating ' $\ldots$ in effect a great outdoor gallery of sculpture. ${ }^{55}$ The original layout can be

48 Valentini and Zuchetti 1953, 385.

49 For this sarcophagus: Rep. I, no. 678; Dresken-Weiland 2003, 377, Kat E 25; and 118 19 for the discovery.

50 Baronio 1601, 724; Bosio 1632, 55.

51 Baratte and Metzger, 1985, 314.

52 Bosio 1632, 69.

53 Paul 2000, 23-27 for a summary of development and brief description of the Villa; also Baratte and Metzger, 1985, 9-11.

54 Baratte and Metzger, 1985, 9-10; Kalveram 1995, 17-25 (especially 23 for gift from Paul V of sarcophagi discovered in excavating foundations of S. Peter's), 156-58.

55 Hermann Fiore 2008, 219, and 221-26 for other examples in Rome. 
largely reconstructed from early guide-books to the Villa; but just how far there was an underlying theme to the choice and arrangement of the ancient images has been disputed by recent scholars. ${ }^{56}$ It is hard to believe that there was none, yet nothing obvious seems to have emerged. A recent study has suggested a general theme to do with 'magnificence and the 'presence' of a Rome triumphing in the sign of Christian love', in which fragments of Christian sarcophagi were used to play an important symbolic role - in fact it was the first case of Christian antiquities being incorporated into the decoration of such a building, and a reflection of the interest stimulated by the new Christian archaeology, and in how it related to the pagan past. ${ }^{57}$

The front panel of this sarcophagus, showing Christ and the apostles, was immured on the front face of the southern belvedere overlooking the giardino segreto of the Villa, and the two side panels placed together in a corresponding position on the north. ${ }^{58}$ In each case they occupied quite a prominent position, for though the walls they decorated stood back some way from the Villa's front facade, they technically formed part of this, its most important aspect, and were the sole decorative feature at that register of decoration. Looking up and down on the south side a viewer would see the relief of Christ and apostles set below a roundel with a bust of Claudius, and a relief of putti with swags, and above a roundel depicting a philosopher and two panels of a mounted soldier and a battle. The north showed a similar melange of subjects: above the panel composed of the two small sides of the sarcophagus was a roundel containing a now unidentified subject and a boar-hunt, while below it was a roundel with a putto with a griffin, and reliefs of Hercules and of a youth. Thus the walls presented a balance of forms and ideologies, juxtaposing subjects that had been prominent in Roman imperial and early Christian art.

The back of the sarcophagus was divided into seven pieces which were similarly immured with other ancient fragments and contemporary ornament in decorative facades in the second recinto of the Villa's gardens. ${ }^{59}$ The figure of the shepherd was described in situ by both Manilli (who identified it as Christ)

56 Guide-books: Manilli 1650, and Montelatici 1700. For reconstructions and discussions: Kalveram 1995 and Hermann Fiore 2008, especially 220 for a summary.

57 Hermann Fiore 2008, 226, 239. Cf. also Federici 2002, 277.

58 Manilli 1650; Montelatici 1700; Kalveram 1995, Anghang III; Hermann Fiore 2008, 233, 236-37, figs, 24, 25 and 235, fig.23. For the two side panels placed together Martinez 2004, 469, no. 0949 (I am very grateful to Jean Luc Martinez for this reference).

59 Wilpert 1923-24, 172-74, fig.4 (in the so-called Prospettiva di Levante, not the Teatro, as Wilpert calls it); cf. Campitelli 2003, 154-56 for present day review, with replacement figures. For display of ancient sculptures in the Villa's grounds: Kalveram $1995,80-88$. 
and Montelatici. ${ }^{60}$ Figured panels were placed under ornamental niches and strigillated panels decorated areas of the wall below the main relief. During the cutting up of this back panel the upper borders of the strigillated panels seem to have been discarded.

While these sections of the back remained in situ until 1920s, when they were identified for what they were, published by Wilpert (in the article from which this paper's opening quotation was taken), and removed to the Capitoline collections in Rome (and now to the Centro Montemartini), the front and side panels of the sarcophagus entered yet another stage in their history. Nearly two hundred years after they were put on the façade, the reliefs were removed and transported to Paris, sold with other antiquities by Camillo Borghese to his brother-in-law, Napoleon Buonaparte in the agreement of 27 September $1807 .^{61}$ It is not entirely clear if Camillo Borghese initiated the sale as a solution to financial difficulties, or whether he was forced by Napoleon who wanted to add this great collection to the Italian art-works he had already removed to France as spoils of war. ${ }^{62}$ In 1816, after Napoleon's defeat and the restitution to Italy of the plundered art-works, Camillo Borghese made an unsuccessful bid to retrieve them. ${ }^{63}$

Once in France the sculptures were displayed in the courtyard of the Musée Napoléon which had been established in 1793 at the Palais du Louvre, as a public museum, where they joined other artistic masterpieces taken by Napoleon from European cities. ${ }^{64}$ Despite the different function of the building in which they now found themselves, they were still treated primarily as decorative items, and had simply exchanged their position on the Villa's walls for display on the Museum's. ${ }^{65}$ This view may explain why it was not until some restoration work was done on the three panels in 1983 that the two side panels

60 Manilli 1650,143; Montelatici 1700, 70-71.

61 Hermann Fiore 2008, 219-220 for uncertainty about when the sculptures were actually removed from facades; she argues that it was on the sale to Napoleon. The Louvre Inventory of 1810 quotes a price of 4000 francs for the two small sides together, and 3000 for the front: Martinez 2004, 469, nos. 0949 and 0950. (I have been unable to access the recent book on the sale by J.-L.Martinez, 1807 L'achat de la collection Borghèse).

62 Baratte and Metzger 1985, 11.Boyer 1969, 197, n. 2 cites the relevant archival sources, and (198) claims that Camillo Borghese was in financial difficulties. For other views see Paul 2000, 80 n. 177. For art-works taken by Napoleon from Italy during 1796, and their later restitution: Miles 2008, 319-348.

63 But afterwards he and his successor, managed to restore the Villa and its collections to much of its earlier splendour through new acquisitions and displays: Boyer 1969, 202; Paul 2000, 80-81; Hermann Fiore 2005, 123.

64 For setting: Martinez 2004, 469.

65 Baratte and Metzger, 1985, 11. 
were separated, and re-assembled with the front, so that as now they could be shown for what they were - namely, three panels of a city gate sarcophagus.

In 2000-2001 they were temporarily reunited with the back (now in the Capitoline Collections in Rome) for the exhibition 'Aurea Roma. Dalla città pagana alla città Cristiana'. They were displayed separately (and have two separate catalogue entries, written by a French and by an Italian scholar). ${ }^{66}$

\section{Conclusions}

Constructing biographies like these is intricate work, with details to be pieced together and gaps and discrepancies to be negotiated (and unfortunately contains plenty of scope for creating and perpetuating errors). At this stage it might seem the ultimate exercise in positivism, but the point is to record the various events in the lives of the sarcophagi so that they provide '.... a rich array of vantage points and approaches for understanding different trajectories in the human valuation of things, ${ }^{67}$ This section of the paper now moves on to do this. It first revisits each biography to identify particular 'vantage points' in the different values they involve, and then looks at all three together.

\section{'The Pianabella sarcophagus', Ostia}

The biography of 'The Pianabella sarcophagus' immediately suggests two important themes, to do with financial and cultural value. Its value as an expensive and beautiful commodity may explain why it was selected for re-use in the third century, and almost certainly was a reason - if not the only one - why it was then buried in the tomb, with liquid mortar used to secure a tight fit. Its commercial value to robbers was enduring, as is shown by the action of the twentieth century looters and of the dealers who bought from them. More precisely, it was the value that resided in the high quality of the figured decoration that counted to them, as they left behind the rest of the sarcophagus which was presumably not worth their while extracting from the site. At any rate the figured scenes had enough financial value to make even the fragmentary piece attractive to the art-market; their fate raises ethical issues which involve a whole series of players, from looters to dealers, collectors, and museum authorities. $^{68}$

66 Ensoli and La Rocca 2000, 607-608, nos. 308 (C. Metzger for the Louvre panels) and 309 (S. Ensoli for the Capitoline).

67 Binsbergen 2005, 22.

68 As discussed for instance in Lundén 2004, 222. 
The figured scenes also proved valuable to twentieth century scholars because of their iconographical worth. Although the clandestini were most likely unaware of this additional value, the images turn out to be unique in combining elements from Greek and Roman iconographies of Achilles. Thus the sarcophagus drew on two cultures. Reflecting contemporary Roman interest in Hellenic culture in the wake of the 'Second Sophistic', it celebrated Hellenism in choosing to depict events from the Iliad; but in using them to stand for universal experiences of death and loss, it was part of a Roman tradition of representing the human condition by reference to mythology and the heroic past. This linking of two cultures through the decoration is paralleled in the life of the sarcophagus itself, through the solution negotiated between cultural authorities in Germany and Italy in the late twentieth century. After its Ostian provenance was clarified, it was agreed that the sarcophagus should go to the Museum of Ostia as a permanent loan from Berlin, and hopes were expressed that this might lead to mutual benefits in terms of collaborative publications and a focus on authenticated excavated material. ${ }^{69}$

\section{'The Brothers sarcophagus', Pisa}

The biography of the sarcophagus in Pisa offers two major themes, which give rather different trajectories to the evaluation. The first is more historicist, and relates to the meaning which the sarcophagus and its decoration seems to have had in terms of family and society. Just as the Roman parents might have taken this half-finished sarcophagus for the chance it offered to personalise the decoration for their dead sons, so too the Falconi may have chosen it because the figures added by the Roman family - the soldier, the young men engaged in public affairs, and the decorously presented woman - also represented their own ideals. As if to confirm this, they inscribed their own family name upon it and added a heraldic device between the central figures.

The second theme is to do with space, and the contrasting states of fixed and mobile, religious and secular, and the different values these entail. Mobility, represented by the long journeys from quarry to Rome and centuries later from Rome to Pisa, involved commercial transactions and the value of the sarcophagus as a prestige import. But then 'fixed' in the Camposanto its values changed and accumulated as the significance of the Camposanto changed around it, from religious shrine and burial place to a secular museum of both Roman and Pisan antiquities. Decorated with figures that embodied Roman civic virtues, the sarcophagus acquired further value as a symbol of Pisa's own glorious past as a new Rome.

69 Heilmeyer 1992, 267. 


\section{'The Borghese sarcophagus', Paris and Rome}

'Fixed' and 'mobile' are qualities also important in the biography of the 'Borghese sarcophagus' - especially in the move from religious, interior space to secular, external display - but it also offers two other themes to consider.

The first is the agency of powerful men, whose famous names dominate its life history. Its precise connection with the earliest of these, Sextus Claudius Petronius Probus, is hard to clarify although the sarcophagus was found in his mausoleum (and may even have been intended for him). For the Borgheses, Scipione and Camillo, and for Napoleon, the sarcophagus meant something collectable, a possession which represented civilisation, learning, the authority of the past, and money. But valued in this way it was also exposed to unsympathetic treatment, in transactions of power and money, and worse still, to be dismembered for display. Napoleon's acquisition of the Borghese antiquities resulted from his power (in whatever respect) over Camillo Borghese at the time, and although it came at the very high price of 13 million francs (which was far more than the 'expert' valuations had predicted) it was seen in Rome at least as little short of plunder. ${ }^{70}$ Protests raised against the sale emphasised the loss to the Roman people in aesthetic, historic and legal terms; it was a loss more acute since the city had already lost many of its classical masterpieces as spoils of war. ${ }^{71}$ But for Napoleon the purchase was intended to reinforce the cultural power of France, to turn Paris into '... the new Rome, the artistic capital of the Western world, superseding even its model and symbolising, inseparably, the succession of France to the centre of Western power, its line of descent ultimately reverting to antiquity. ${ }^{72}$ Once again the romanitas of the sarcophagus was of prime importance.

The second aspect is didactic - which underlies the display of this sarcophagus ever since its discovery. Even though damaged, it aroused great interest in Counter-Reformation Rome since its images could be directly linked with one of the most prominent families of early Christian Rome. So the 'Father of Ecclesiastical History', Cardinal Cesare Baronio published it in his great Annales ecclesiatici $(1598-1607)$ as evidence for the piety of early Christians which he could set before his readers for their spiritual edification. ${ }^{73}$ The Anicii made good exemplars for his cause since Probus was a famous senatorial convert to Christianity, and Proba celebrated for her good works and the head of several generations of leading Christian women. To support his text he provided a (rather inaccurate) illustration of the front panel. In contrast, Antonio Bosio's

70 Boyer 1969, 197-202.

71 Hermann Fiore, 2005; Miles 2008, 319-348.

72 Paul 2000, 80.

73 Baronio 1601, 724. He directly addresses the reader in the second person. 
approach to the sarcophagus made a particular point of archaeological accuracy, and he systematically illustrated all four sides of the sarcophagus which he claimed to have inspected personally. This new interest in early Christian archaeology in early seventeenth century Rome presumably explains why these Christian reliefs were included in the decoration of the Casino of the Villa Borghese (particularly if this was to be read as a programmatic exploration of links between pagan and Christian antiquity). The culmination of this didactic aspect was in the systematic displays of the Louvre (which had become a public state museum in 1793), designed as they were to educate the visiting public. $^{74}$

Looking now at all three biographies together, certain common features emerge which suggest the effectiveness of this as a methodology. To begin with a caveat: in terms of their record, all three show a similar imbalance in the evidence on which they are based, with large gaps for the start of the 'lives' and much better documentation towards the end. This is scarcely surprising given how hard it is to piece together anything much about the earliest stages in the production and usage of any Roman sarcophagus (let alone the identities of their original owners), while more recent situations are often well documented in museum inventories or catalogues. Yet even so, each involves a 'life event' or visual feature which helps fill some of these gaps in their record. For instance, particular iconographical details suggest that they all may have started life as special commissions, while information from other imported lion heads' sarcophagi allows more to be understood about the background to the decoration on the sarcophagus in Pisa. As for establishing evidence for more recent events in their existence, two involved contrasting means: at Pianabella it took a systematic investigation to ascertain the provenance of the front panel, while a fortuitous recognition appears to have identified the back panel of the 'Borghese sarcophagus' in the Villa grounds. All three sarcophagi now display the physical effects of their major life events: the 'Pianabella sarcophagus' is badly damaged, the 'Borghese sarcophagus' separated into sections (distributed across two countries), while the Pisan sarcophagus has been inscribed with an owners' name.

On the other hand, these biographies offer two distinctive opportunities as an interpretative tool - to look across the entire 'life-span' of an individual sarcophagus, and to allow the identification of common values or recurring patterns in significance.

The chance to review the whole existence of a sarcophagus, from quarry (if possible) to its present-day location, is especially important as it does away with the artificial boundaries of period (especially between antiquity, the Middle ages and the Renaissance), and is also a reminder of how often other accounts of re-

74 Paul 2000, 88. For the opening of the Louvre, McClellan, 1994, 94-98. 
use tend to privilege the sarcophagus at one particular point in time. In fact it is clear from the Pianabella and Pisa sarcophagi (and from many other cases recorded by Dresken-Weiland 2003, for instance) that the adaptation, re-use, and re-location of sarcophagi frequently happened in antiquity (often not long after a sarcophagus first came into use), and that it would be more accurate to see this as a practice that happened as a continuum across centuries, rather than with supposedly decisive breaks between antiquity and the Middle ages. But it does also demand a tighter analysis than is often made of changes in social and cultural values that took place in Rome during antiquity, to achieve a better understanding of what was signified by the burial of the re-used Pianabella sarcophagus, for instance, or whether the (apparent) burial of Christian sarcophagi in the Mausoleum of the Anicii had the same meaning a century or so later. Were they both interred for reasons of security, for instance, or were there ideological grounds for burying the Christian sarcophagi below the mausoleum floor $?^{75}$ The need to consider closely what was involved at every stage seems a very positive aspect of the biographical method.

Comparing biographies, such as these, offers the important chance to identify common or recurrent elements. The discussion which follows will focus on three which, in different ways, are particularly useful for identifying how meanings get attached to sarcophagi through different human social actions.

Each biography has demonstrated re-use for aesthetic or ideological motives (sometimes both together, as in the decoration of the Villa Borghese). These are aspects of re-use which are well-known from studies that are period- or locationbased; but biography makes it possible to see how they varied across time and function. Take, for example, the re-use of sarcophagi as an appeal to the authority of the past which occurs as a virtual constant, but in several different forms. In medieval Pisa it had particular value to the elite who used romanitas as an ideal which confirmed their own power and that of their city. In early seventeenth century Rome, the past which was cited through aesthetic and ideological references was both pagan and early Christian, and provided a theme through which leading figures in Papal Rome could negotiate their own contemporary priorities, whether cultural or driven by the needs of the Counter Reformation. Yet another aspect of the authority of the past emerges in the museological drives of the late eighteenth and early nineteenth centuries when systematic displays become important means of showing the value of local heritage or universally important art-works. In Rome, Paris and Pisa questions were asked about cultural ownership which show that the past at issue was not exclusively that of ancient Rome; for by that time the Borghese collection of antiquities is perceived of as being part of the patrimony of contemporary

75 Cf. also Barbavara di Gravellona 2002, 208 for invisibility of tombs, buried 'humile e depressum' below church floors. 
Rome, and the sarcophagi in Lasinio's Camposanto important as evidence of Pisa's glorious medieval past. Nearly two centuries later 'the Pianabella sarcophagus' is returned to be displayed as part of Ostias history (although on permanent loan from Berlin). Biography, in short, is a good way of revealing how values attached to a particular sarcophagus can accumulate across centuries, but may also shift in emphasis in response to changing historical contexts.

Another theme that emerges from these three biographies concerns display, and more precisely the states of being hidden and viewable; and this is especially interesting given recent debate about the role of the viewer in relation to Roman sarcophagi, in terms of giving meaning to the visual image. ${ }^{76}$ 'The Pianabella' and 'the Borghese' Sarcophagi are powerful illustrations of how one sarcophagus may move from one of these states to another, changing not only significant context but also the degree of visibility to a viewer. It is not known how 'the Pianabella' sarcophagus was originally displayed, but there is no particular reason to suspect that it was hidden entirely from view, but the way it was buried in the third century made it conclusively invisible, until centuries later its more spectacular sections were sheared off and ended up on public display (now happily visible with the rest in Ostia Museum). If burial was a strategy to ensure the security of this sarcophagus, then it was successful for a long while. The fate of 'the Borghese sarcophagus' was even more striking in this respect: long hidden from view (and perhaps even buried) it escaped destruction along with its mausoleum, only to be 'preserved' by being dismembered and publically displayed on a high profile building. This new context enforced new readings on to its separated panels through association with the other reliefs with which they were juxtaposed. Even in its current places of display, this sarcophagus is no longer visible as an entity, leaving visitors to supply the missing sections from a combination of knowledge and imagination. Again, comparisons of biographies can show how such vicissitudes are a regular feature of the lives of sarcophagi, but they also suggest that things can change again: perhaps the separated panels of the 'Borghese sarcophagus' might yet again be permanently reunited like that of Pianabella. The fates of sarcophagi need not end up as 'rather sad'. ${ }^{77}$

A third feature to emerge from comparing these biographies is just how often sarcophagi are regarded as 'empty vessels' waiting to be filled with a personal identity. There is a real sense that as one set of bones gets removed from the sarcophagus (and to where?), some new, living body is ready to appropriate it for a fresh purpose and a fresh identity. ${ }^{78}$ The Falconi literally

76 E.g. Dresken-Weiland 2003, 185-98; also Barbavara di Gravellona 2002 for this as an issue in the re-use of sarcophagi.

77 Wilpert 1923-24, 168-69.

78 I am grateful to Jessica Hughes for reminding me to put the bodies back into these sarcophagi, but tracing - even generally - the comings and goings of bones and bodies is 
inscribed their new identity on to the Roman sarcophagus which they re-used in contrast to the new Roman owner of the sarcophagus at Pianabella, who seems to have erased its original inscription before he buried it. ${ }^{79}$ Wilpert even saw one of the heads restored on the Borghese sarcophagus in the Louvre as having the features of Napoleon III. ${ }^{80}$ But even now it is apparently hard to resist suggesting personal identities and motivations for the unknown people who commissioned or used the sarcophagi (such as the Roman and Pisan families, or the Egrili at Ostia). The whole debate about which of the two sarcophagi found in the Mauseoleum of the Anicii actually contained the body of Probus shows how important a 'big name' might be for the future evaluation of a sarcophagus - and also much may hang on a twist of fate. For, as Schoenbeck observed, a quirk of preservation - of the gold-threaded fabric allegedly found inside the columnar sarcophagus - instantly gave that one a glorious and certain identity, and consigned the other to a life in its shadow. ${ }^{81}$ The power of the label in shaping the meanings invested in a sarcophagus has been demonstrated by Elsner in his discussion of how sacred and secular values were constructed for Roman sarcophagi re-used in Provence across several centuries. $^{82}$

Another facet of the attachment of value through names is the naming of the sarcophagi themselves. It is noticeable how each of these three sarcophagi has acquired a title - 'the Pianabella sarcophagus', 'the Brothers' or 'the Tabernacle sarcophagus' at Pisa, and 'the Borghese sarcophagus'. (The first comes from provenance, the second from iconographical features, and the third from the collection: so like the naming of Pompeian houses or Greek vase painters, the process is rather random and privileges one particular aspect of the objects' life). Names like these make for obvious ease of reference in discussions (as here), but each of these is used in a principal publication of the sarcophagus concerned as if it is some official term, or has some intrinsic proprietorial value.

In conclusion, writing biography is necessarily a partial affair, and this is true for objects as it is for people: I have written and interpreted these three sarcophagi conscientiously, but from my own viewpoint and inevitably imperfect knowledge. These biographies are also limited, as they can only ever be partial accounts of the whole phenomenon of re-used Roman

not so easy, apart from occasional insights. For instance, Baronio 1601, 723 recorded the re-burial of bones from the so-called Probus sarcophagus in the Vatican, and see Donati 1993, 94 for Lasinio's treatment of the human remains he found in sarcophagi entering the Camposanto in Pisa.

79 Paroli 1999, 221.

80 Wilpert 1923-24, 173-74.

81 Schoenebeck 1935, 112-13 despite what he saw as its stronger claims to be that of Probus and his wife.

82 Elsner 2009. 
sarcophagi, illuminating only those aspects which are represented in the individual life histories. Inevitably they yield much more when they can be compared with each other. Yet necessary as they are, these provisos are small in comparison with the benefits to be gained from treating sarcophagi as 'things', or 'objects' and approaching them biographically. This method '...can make salient what might otherwise remain obscure,' and this has the great advantage of being able to accommodate the wide variety of uses and contexts that they involve. ${ }^{83}$ It thus provides an inclusive base from which to consider the values and meanings that different societies have invested in their use of them.

\section{Bibliography}

Andreae, B. Bossierte Porträts auf römischen Sarkophagen - ein ungelöstes Problem, in: B. Andreae (ed.), Symposium über die antiken Sarkophage, Pisa 5.-12. September 1982 (Marburger Winckelmann-Programm, 1984), 109-128.

Andreae B. and Settis, S. (eds.). Colloquio sul reimpiego dei sarcophagi romani nel Medioevo, Pisa , 5-12 settembre 1982, Marburger Winckelmann-Programm 1983 (Marburg, 1984).

Appadurai, A. (ed.). The Social Life of Things (Cambridge, 1988).

Arias, P. E. Cristiani, E. and Gabba, E. Camposanto monumentale di Pisa. Le antichità. II sarcofagi romani, iscrizioni romane e medioevali (Pisa, 1977).

Baracchini, C. (ed.). I marmi di Lasinio. La collezione di sculture medievali e moderne nel Camposanto di Pisa (Florence, 1993).

Baracchini, C. and Castelnuovo, E. (eds.). Il Camposanto di Pisa (Biblioteca di storia dell'arte 27) (Turin, 1996).

Baracchini, C. Il restauro infinito, in: Il Camposanto di Pisa (Biblioteca di storia dell'arte 27), edited by C.Baracchini and E. Castelnuovo (Turin, 1996), 201-212.

Baratte, F. and C. Metzger. Catalogue des sarcophages en pierre d'époques romaine et paléochrétienne (Paris: Éditions de la Réunion des musées nationaux, 1985).

Barbavara di Gravellona, T. Visibilità effimera, visibilità negata: sarcofagi romani reimpiegati e obliterati nel medioevo, in: Senso della rovine e riuso dell'antico (Annali della scuola normale Superiore di Pisa Quaderni 14), edited by W. Cupperi (2002), $199-217$.

Baronio, C. Annales Ecclesiastici IV (Antwerp, 1601).

Binsbergen, W. van and Geschiere, P. (eds.). Commodification. Things, agency and identities; the social life of things revisited (Münster, 2005).

Bober, P. and Rubinstein, R. Renaissance artists and antique sculpture (Oxford, 1986).

Bosio, A. Roma sotterranea (Rome, 1632).

Boyer, F. L'achât des antiques Borghèse, in: Le monde des arts en Italie et la France de la Révolution et de l'Empire, (Biblioteca di studi francesi, 4), edited by F. Boyer (Turin, 1969), $197-202$.

Brilliant, R. I piedistalli del giardino di Boboli: spolia in se, spolia in re. Prospettiva 31.4 (1982), 2-16.

83 Kopytoff 1988, 67. 
Brown, P. Aspects of the Christianization of the Roman Aristocracy. Journal of Roman Studies 61 (1961), 1-11.

Campitelli, A. Villa Borghese da giardino del principe a parco dei romani (Rome, 2003).

Casini, C. Ultimus morientis et primus resurgentis artis gradus La disposizione delle sculture in Camposanto, in: I marmi di Lasinio. La collezione di sculture medievali e moderne nel Camposanto di Pisa, edited by C. Baraccini (Florence, 1993), 61-72.

Cupperi, W. (ed.). Senso della rovine e riuso dell'antico (Annali della scuola normale Superiore di Pisa Quaderni 14) (2002), 273-285.

Cutler, A. Re-use or use? Theoretical and practical attitudes towards objects in the early middle ages' in: Ideologie e practiche del reimpiego nell'alto medioevo. Settimane d studio del centro italiano di studi sull'alto medioevo 26. 16-21 aprile 1998 (Spoleto, 1999), 1055-1079.

Donati, F. and Parra, M. C. Pisa e il reimpiego 'laico': la nobiltà di sangue e d'ingegno, e la potenza' in: Colloquio sul reimpiego dei sarcophagi romani nel Medioevo, Pisa , 512 settembre 1982, Marburger Winckelmann-Programm 1983 (Marburg, 1984), edited by B. Andreae and S. Settis, 103-119.

Donati, F. Storia della collezione. Raccolta delle opera antiche in: Camposanto monumentale di Pisa. Le antichità II, edited by S. Settis (Modena,1984), 9-34.

Donati, F. Genesi e formazione della collezione di antichita del Camposanto, in: I marmi di Lasinio. La collezione di sculture medievali e moderne nel Camposanto di Pisa, edited by C. Baraccini (Florence, 1993), 87-107.

Donati, F. Il reimpiego dei sarcofagi. Profilo di una collezione, in: Il Camposanto di Pisa (Biblioteca di storia dell'arte 27), edited by C. Baracchini and E. Castelnuovo (Turin, 1996), 69-96.

Dresken-Weiland, J. Sarkophagbestattungen des 4-6 Jahrhunderts im Westen des römischen Reiches (Römische Quartalschrift 55 Supplementband) (Rome, 2003).

Elsner, J. The Christian Museum in the South of France: Antiquity, Display and Liturgy from the Counter-reformation to Aftermath. Oxford Art Journal 32, 2 (2009), 181 204.

Ensoli, S. and La Rocca, E. (eds.). Aurea Roma. Dalla città pagana alla città Cristiana (Rome, 2000).

Federici, F. Veterum signa tanquam spolia. Aspetti del reimpiego di sculture antiche a Roma nel seicento, in: Senso della rovine e riuso dell'antico (Annali della scuola normale Superiore di Pisa Quaderni 14), edited by W. Cupperi (2002), 273-285.

Giuliani, L. Achill-Sarkophage in Ost und West: Genese einer Ikonographie. Jahrbuch der Berliner Museen 31 (1989), 24-39.

Gosden, C. and Marshall, Y. The cultural biography of things. World Archaeology 31.2 (1999), 169-178.

Greenhalgh, M. The Survival of Roman Antiquities in the Middle Ages (London, 1989).

Harlow, M. and Laurence, R. Growing up and Growing old in ancient Rome. A life course approach (London, 2002).

Heilmeyer, W.D. Antikenwanderungen. Ostia und Berlin tauschen Skulpturen und Wandmalereien aus, Antike Welt 23.4 (1992), 263-267.

Hermann Fiore, K. Antonio Canova 1807: un memoriale a Pio VII in difesa del diritto del populo romano contro la vendita dei marmi della collezione Borghese a Napoleone, in: Villa Borghese. Storia e gestione. Atti del convegno internazionale di Studi Roma, British School at Rome 19-21 giugno 2003, edited by A. Campitelli (Milan, 2005), 113-129.

Hermann Fiore, K. The exhibition of sculpture on the Villa Borghese Facades in the time of Scipio Borghese, in: Collecting Sculpture in early modern Europe (Studies in 
the History of Art 70. Symposium Papers 47), edited by N. Penny and E. D. Schmidt (Washington 2008), 219-245.

Hoskins, J. Agency, biography and objects, in: Handbook of Material Culture, edited by C. Tilley (London, 2006), 74-84.

Jones, A.H.M., Martindale, J. and Morris, J. The Prosopography of the Later Roman Empire Vol. I, AD 260-395 (London, 1971).

Kalveram, K. Die Antikensammlung des Kardinals Scipione Borghese (Römische Studien della Biblioteca Hertziana Band 11) (Worms, 1995).

Koch, G. Frühchristliche Sarkophage. Handbuch der Archäologie (Munich, 2000).

Koch, G. and Sichtermann, H. Römische Sarkophage. Handbuch der Archäologie (Munich, 1982).

Kopytoff, I. The cultural biography of things: commoditization as process, in: The Social Life of Things, edited by A. Appadurai (Cambridge, 1988), 64-91.

Liverani, P. La topografia antica del Vaticano (Vatican City, 1999).

Llewellyn, N. The Art of Death. Visual Culture in the English Death Ritual c. 1500 c.1800 (London, 1991).

Lundén, S. The Scholar and the Market. Swedish scholarly contributions to the destruction of the world archaeological heritage, in: Swedish archaeologists on ethics, edited by H. Karlsson (Lindome, 2004), 197-247.

Manilli, J. Villa Borghese fuori di Porta Pinciana (Rome, 1650).

Martinez, J.L. Les antiques du Musée Napoléon. Édition illustré et commentée des volumes $V$ et VI de l'Inventaire du Louvre de 1810. Notes et documents des musées de France 39 (Paris, 2004).

Matthews, J. Four Funerals and a Wedding: This World and the Next in FourthCentury Rome, in: Transformations of Late Antiquity: essays for Peter Brown, edited by P. Rousseau and E. Papoutsakis (Farnham, 2009), 129-146.

McClellan, A. Inventing the Louvre. Art, politics, and the origins of the modern museum in eighteenth century Paris (Berkeley and London, 1994).

Miles, M. Art as Plunder. The ancient origins of debate about cultural property (New York and Cambridge, 2008).

Milone, A. Il camposanto, museo immaginato, tra seicento e settecento, in: I marmi di Lasinio. La collezione di sculture medievali e moderne nel Camposanto di Pisa, edited by C. Baraccini (Florence, 1993), 19-36.

Montelatici, D. Villa Borghese fuori di Porta Pinciana con l'ornamenti, che si osservano nel di li palazzo, e con le figure delle statue più singolari (Rome, 1700).

Morandi, A. Il sarcofago di Pianabella. Archeologia Laziale 11 (1993), 149-154.

Paroli, L. La basilica cristiana di Pianabella, Scavi di Ostia XII (Rome, 1999).

Paul, C. Making a Prince's Museum: Drawings for the late eighteenth century redecoration of the Villa Borghese (Los Angeles, 2000).

Penny N. and Schmidt, E. D. Collecting Sculpture in early modern Europe (Studies in the History of Art 70. Symposium Papers 47) (Washington, 2008).

Prettejohn, E. Reception and ancient art: the case of the Venus de Milo, in: Classics and the Uses of Reception, edited by C. Martindale and R. Thomas (Malden, Mass. and Oxford, 2006), 227-249.

Ragusa, I. The Re-use and Public Exhibition of Roman sarcophagi in the Middle Ages and early Renaissance. (Unpublished MA Dissertation, New York University, 1951).

Robb, J. Time and biography. Osteobiography of the Italian Neolithic Lifespan, in: Thinking through the Body, edited by Y. Hamilakis, M. Pluciennik and S. Tarlow (New York and London, 2002), 153-171.

Robert, C. Roman sarcophagi at Clieveden Journal of Hellenic Studies 20 (1900), 81-98 
Rowlands, M. Value and the cultural transmission of things, in: Commodification. Things, agency and identities; the social life of things revisited, edited by W. van Binsbergen and P. P. Geschiere (Münster, 2005), 267-281.

Sansoni, R. I sarcofagi paleocristiani a porte di città (Studi di antichità cristiane 4) (Bologna, 1969).

Schoenebeck, H. von. Der Mailünder Sarkophag und seine Nachfolge (Vatican City, 1935).

Settis, S. Camposanto monumentale di Pisa. Le antichità II (Modena, 1984).

Settis, S. Continuità, distanza, conoscenza, tre usi dell' antico, in: Memoria dell'antico nell'arte italiana, edited by S. Settis (Turin, 1986), 375-486.

Settis, S. Riusare l'antico, mutare il presente, in: Roma: il riuso dell'antico: fotografie tra XIX e XX sec., edited by G. Borghini, P. Callegari and L. Nista (Bologna, 2004), 11 18.

Settis, S. Collecting ancient sculpture: the beginnings, in: Collecting Sculpture in early modern Europe (Studies in the History of Art 70. Symposium Papers 47), edited by N. Penny and E. D. Schmidt (Washington 2008), 219-245.

Stenbro, R. Kunstwollen und Spolia. On the methodological and theoretical foundation of spolia research and the positions adopted towards it. Analecta Romana Instituti Danici 31 (2005), 59-76.

Tolaini, E. Pisa. Quando i sarcofagi entrarono in Campo Santo. Critica d'arte 33-34 (2008), 51-56.

Valentini, R. and Zuchetti, G. Codice topografico della città di Roma IV (Rome, 1953).

Verkerk, D. Life after Death: the afterlife of Sarcophagi in medieval Rome and Ravenna, in: Roma Felix: Formation and Reflections of Medieval Rome, edited by E. Ó Carragáin and C. Neuman de Vegvar (Aldershot and Burlington VT, 2007), 81 96.

Walker, S. The marble quarries of Proconnesos: isotopic evidence for the age of the quarries and for lenos-sarcophagi carved at Rome, in: Marmi antichi. Problemi d'impiego, di restauro, e d'identificazione. Studi Miscellanei 26, edited by P. Pensabene (Rome, 1981-1982 [1985]), 57-65.

Ward-Perkins, J. B. and Throckmorton, P. New Light on the Roman Marble trade. The San Pietro Wreck. Archaeology 18 (1965), 201-209.

Wilpert, J. I sarcofagi cristiani antichi I - III (Vatican City, 1929-36).

Wilpert, J. Appunti su alcuni sarcofagi cristiani. Rendiconti della pontificia accademia romana di archeologia (1923-24), 169-184.

Wrede, H. Senatorische Sarkophage Roms: der Beitrag des Senatorenstandes zur römischen Kunst der hohen und späten Kaiserzeit (Monumenta artis Romanae 29) (Mainz, 2001).

Zanker, P. and Ewald, B. C. Mit Mythen leben. Die Bilderwelt der römischen Sarkophage (Munich, 2004). 